Vlasta Jalušič**

\title{
Arendt, Koselleck, and Begreifen: Rethinking Politics and Concepts in Times of Crisis'
}

Hannah Arendt and Reinhart Koselleck are two of the most outstanding scholars of history and political thinking of the $20^{\text {th }}$ century. While Arendt ushered in an unprecedented approach in political thinking, which is often misunderstood and accompanied by controversies, Koselleck created one of the most systematic opuses of the analysis of fundamental concepts in their historico-political dynamic and established conceptual history as a historical method. This article looks at some important intersections between Arendt's and Koselleck's thinking of political concepts and politics. At the forefront are both authors' respective thesis about the gap, rupture, or break in tradition (of political thinking and historical periods), the way they conceptualise concepts and the role thereof in thinking through times of crisis, and how this relates to their understanding of politics and the political. The inquiry has no ambition to carry out a "comparison" in a strict manner. The aspect of direct connections and influences between authors is rather one sided as only Koselleck refers to Arendt's work. However, there are commonalties (and differences) arising from their shared intellectual-historical horizon, study background, and individual experience, which inform their eventual mutual "thinking space."2 Focusing on the question of both authors' Begreifen in times of crisis and breaks in the political tradition, I take into consideration the direct as well as indirect aspects.

This article is a result of the research project J5-1749 "The break in tradition: Hannah Arendt and conceptual change", https://www.mirovni-institut.si/en/projects/the-breakin-tradition-hannah-arendt-and-conceptual-change/ and the research programme $\mathrm{P}_{5}$ 04133 "Equality and human rights in times of global governance", both financed by the Slovenian Research Agency.

2 The expression is borrowed from the exhibition idea of Wolfgang Heuer and Sebastian Hefti, i.e. Hannah Arendt Denkraum, $c f$. Peter Funken, "Hannah Arendt's Denkraum: The Experience of an Experimental Exhibition”, http://www.wolfgang-heuer.com/denkraum/ eng/space.htm, accessed 24 April 2021. 


\section{Bridging Arendt's and Koselleck's thinking space}

Koselleck has long been regarded as a particularly eminent theorist of historical concepts, while Arendt had not been in focus as a conceptual author until recent times. Studies and books that bring both authors' conceptual thinking into a productive dialogue have been published only in the last decade. ${ }^{3}$ They identify their several common research topics: similar conceptions of time; the exploration and critique of the philosophy of history; opposition to thinking in terms of the history of ideas; a non-causal understanding of history and politics; similar considerations about modern secular power; a critique of the notion of progress as anti-political, etc. Barros, for example, tackles the common in historical thinking about the present, past, and future in the two authors, and shows where their otherwise parallel thesis of the break in tradition differs but can be brought into a dialogue. Hoffman identifies the points of contact and parallels between Koselleck's Historik and Arendt's political "anthropology" (relying on experience as one of the central categories) in some of their major works. Maria Pia Lara analyses how Arendt's and Koselleck's concepts of democracy, the state, emancipation, revolution, and the notion of critique relate to the web of a disclosive process of semantic transformation. She argues that conceptual history as a method was used by both authors "to explain the way specific notions of political agency have undergone a change or a transformation."4 Both Hoffman and Lara claim that Koselleck was - to quite an extent - directly influenced by Arendt. Indeed, Koselleck either explicitly refers to her works ${ }^{5}$ or sometimes uses a similar line of argument, the same citations, etc. He started thinking of

3 Cf. José D’Assunção Barros, "Perspectiva sobe o tempo em Hannah Arendt e Koselleck: duas leituras sobre a quebra entre o Presente e o Passado“, Argumentos, 6 (12/2014), pp. 169-189; Stefan-Ludvig Hoffman, "Koselleck, Arendt, and the Anthropology of Historical Experience”, History and Theory, 49 (2/2010), pp. 212-236, Maria Pia Lara, The Disclosure of Politics: Struggles Over the Semantics of Secularization, New York, Columbia University Press, 2013; Sebastian Huhnholz, Von Carl Schmitt zu Hannah Arendt? Heidelberger Entstehungsspuren und bundesrepublikanische Liberalisierungsschichten von Reinhart Kosellecks “Kritik und Krise”, Berlin, Duncker \& Humblot, 2019. I refer here to only those studies that have both authors at the core and not just their particular concepts.

4 Lara, The Disclosure of Politics, p. 31.

5 Niklas Olsen, Beyond utopianism and relativism: History in the plural in the work of Reinhart Koselleck, Florence, European University Institute, 2009, p. 46. Reinhart Koselleck, "Laudatio auf François Furet", in Festschrift zur Vergabe des Hannah-Arendt-Preises für politisches Denken an François Furet, Bremen, Heinrich Böll Stiftung, 1996, pp. 9-12. 
social and political concepts within the semantic web of their construction (and reconstruction). This was in fact similar to Arendt's view that political concepts are intrinsically related to the political experience of those actors or spectators who coined them. Meanwhile, a recent study by Huhnholz which questions the "standard" interpretation of Koselleck's understanding of politics and the "political" in relation to Schmitt, Hobbes, and political tradition, also relativises Koselleck's own claim about the early direct influence of Arendt on him.

These works touch upon several themes that are of interest here: the Western tradition, its crisis, and modernity; rupture, repetition, continuation, and conceptual transformation; both authors' approach to the possibility of historical and political thinking after the rupture, and what conditions and concepts are available/needed for such an endeavour. This last common point is particularly important for this article, as both Arendt and Koselleck express the need for a new kind of political theory or "political science," in which conceptual thinking plays a crucial role.

\section{The importance of the concept}

Apart from Koselleck's monumental work on concepts in their historical dynamic, several approaches to the basic concepts of politics, conceptual change, and history exist within the European research tradition. The differences notwithstanding, they all proceed from either Heidegger's temporal dimension (historical and existential position) or the so-called linguistic turn, and identify some kind of break between the "old" and "modern" world as the origin of modern concepts.? In this context, Koselleck has the status of an undisputed authority on Begriffsgeschichte and international fame as a distinctive and original schol-

\footnotetext{
Hoffman, "Koselleck, Arendt, and the Anthropology of Historical Experience", p. 234. For an overview, see W. Steinmetz, M. Freeden, and J. Fernández-Sebastián (eds.) Conceptual history in the European space, New York and Oxford, Berghahn Books, 2017. The most known and viewed as different from Koselleck's position is the Cambridge School of intellectual history, which focuses on changes in the relation between speech and action. For the relationship between Koselleck and the Cambridge School, see Melvin Richter, "Reconstructing the History of Political Languages: Pocock, Skinner, and the Geschichtliche Grundbegriffe", History and Theory, 29 (1/1990). See also Kari Palonen, Die Entzauberung der Begriffe. Das Umschreiben der politischen Begriffe bei Quentin Skinner und Reinhart Koselleck, Münster, LIT Verlag, 2004 and The Struggle with Time: A Conceptual History of 'Politics' as an Activity, Münster, LIT Verlag, 2014.
} 
ar. ${ }^{8}$ At the centre of the research in Geschichtliche Grundbegriffe lies the resolution of the old and the emergence of the (new) modern world through the lens of social and political conceptuality from 1700 to the $20^{\text {th }}$ century. ${ }^{9}$

The heuristic framework of this work is Koselleck's hypothesis on Sattelzeit (saddle time) which explains the phase of transformation (between the $17^{\text {th }}$ and $19^{\text {th }}$ centuries) from the old paradigm to the formation of the modern paradigm of European concepts (in times of crisis) mostly in categories regarding the break in the traditional connections between the "experienced" (Erfahrenes) and the "expected" (Erwartbares). ${ }^{10}$ The horizon of the "expected" (the future) starts to increasingly dominate the "experienced". The relation between the concept (der Begriff) and the conceptualised (das Begreifene) is inverted. The translocation from the topological into the temporal perspective and conscious de- or re-contextualisation helps to understand how the concept gains a constructive role in history. ${ }^{11}$ Instead of one-meaningness, precisely historicity, politicalness, multi-meaningness, polemicalness, and conceptual change become preconditions for the study of politics, culture, and history. ${ }^{12}$ The history of concepts is no longer an appendix to "social" history, but its driving force.

Koselleck's opus tackled a much wider range of topics than just the project of Geschichtliche Grundbegriffe and included philosophical and epistemological questions as to what history is. In his many essays he demonstrated the need for history and political science as two areas of scholarship to stay close together if we want to draw any "lessons" from the history of concepts (not from the "his-

8 The monumental work of Koselleck and his colleagues, accomplished over the course of several decades, comprises eight volumes of a dictionary of basic concepts (approximately 9,000 pages) covering 122 concepts or clusters of concepts such as revolution, state, rule, democracy, freedom, property, work, etc. See O. Brunner, W. Conze, R. Koselleck (eds.), Geschichtliche Grundbegriffe. Historisches Lexikon zur politisch-sozialen Sprache in Deutschland, Vols. 1-8, Klett-Cotta, Stuttgart, 1972-1997.

9 Cf. Reinhart Koselleck, “Einleitung”, in Brunner et al., Geschichtliche Grundbegriffe, Vol. 1, p. XIV.

$10 \quad$ Ibid., p. XV.

${ }_{11}$ Reinhart Koselleck, "Erfahrungswandel und Methodenwechsel. Eine historisch-anthropologische Skizze“, in Christian Meier, Jörn Rüsen J. (eds.), Historische Methode, Munich, Deutscher Taschenbuch Verlag, 1988, pp. 13-61.

12 Kari Palonen, "An Application of Conceptual History to Itself: From Method to Theory in Reinhart Koselleck's Begriffsgeschifte”, Finnish Yearbook of Political Thought, 1 (1/1997), pp. 39-69. 
tory of ideas"). This close relationship that binds the history of concepts and their (socio-political) context represents one of the main points of intersection between Koselleck and Arendt.

A large portion of Hannah Arendt's work consists of conceptual considerations as well, although not systematically historically. Her accounts at first sight look almost anarchic, like a bricolage, "wandering thought", while rather "systematically" refusing traditional scientific methodology. ${ }^{13}$ Arendt was, mainly for this reason, for a long time not seen as a "conceptual" author. Due to her exceptional knowledge of classical thought, the unusual liveliness of the argumentation in her texts, and the simultaneous intertwining of highly complex theories with a free style of writing, she was often perceived as a somewhat essayistic writer. ${ }^{14}$ Arendt seems to make a similar move as Koselleck, who defines Sattelzeit and the crisis as decisive moments in the transformation of traditional conceptuality. Only that she puts forward a thesis about the "break in (political) tradition," which she historically locates in the total domination in the first half of the $20^{\text {th }}$ century, while the break in theory preceded this. This becomes the negative starting point for thinking through the question of which modern concepts could frame an understanding of the new phenomena; whether these concepts still have a meaning at all, what consequences the break brings for our understanding of the basic concepts of politics (such as power, authority, violence, politics, bureaucracy, nation-state, imperialism, etc.) and how this affects our capacity for action. Arendt's understanding of politics (not of the "political") is

13 Cf. Antonia Grunenberg, "Arendt, Heidegger, Jaspers: Thinking through the Breach in Tradition”, Social Research, 74 (4/2007), Hannah Arendt’s Centenary: Political and Philosophical Perspectives, Part II, pp. 1003-1028. Steve Buckler, Hannah Arendt and Political Theory. Challenging the Tradition, Edinburgh, Edinburgh University Press, 2011; Ernst Vollrath, "Hannah Arendt and the Method of Political Thinking”, Social Research (Summer 1977), pp. $160-182$.

14 Hans Jörg Sigwart, The Wandering Thought of Hannah Arendt, London, Palgrave Macmillan, 2016. It was, however, exactly this essayistic, experimental characteristic of her writing "style" that enabled her to translate the experiential dimension of her thought into meaningful conceptualisations and political thinking, taking into account the horizon of both actors and sufferers in political events. Cf. Wolfgang Heuer, "Verstehen als sichtbarmachen von Erfahrungen”, in W. Heuer and I. von der Lühe (eds.), Dichterisch denken. Hannah Arendt und die Künste, Göttingen, Wallstein, 2007, pp. 243-257, and Ari-Elmeri Hyvönen, “The Janus face of political experience”, Arendt Studies, 2 (2018), pp. 125-147. Not surprisingly, Koselleck's thinking of concepts too, apart from the Lexicon, is mostly written in the form of free style essays. 
based on this retrospective view from the point of rupture (between past and future) and establishes a specific framework for the reformulation of other basic concepts.

In the following, I first elaborate on the importance of the break in tradition and crisis as an incentive for conceptual thinking in both authors. I note that in fact both Arendt and Koselleck consider multiple breaks in tradition and not just one. Then, I examine their understanding of Begreifen, how they link it to the experience of the rupture in tradition and how this relates to their understanding of politics and the political, i.e. to their specific political conceptuality. I conclude that there exists a common thinking space between Arendt and Koselleck concerning Begreifen: in spite of their different concepts of politics and the political, their thinking of the breaks in time and crisis can be read as complementary: especially their effort to return the responsibility for actions and concepts to the human sphere.

\section{The break in tradition: thinking from the rupture in time}

Totalitarian domination [...] which [...] cannot be comprehended through the usual categories of political thought, and whose 'crimes' cannot be judged by traditional moral standards or punished within the legal framework of our civilization, has broken the continuity of Occidental history. The break in our tradition is now an accomplished fact. ${ }^{15}$

Both Arendt and Koselleck proceed from experience as a central category in their conceptual inquiries, and from there they both strive to understand the conditions for their respective subject of interest (primarily history in Koselleck and politics in Arendt).${ }^{16}$ Arendt's rethinking of concepts is based on her and others'

15 Hannah Arendt, Between Past and Future. Eight Exercises in Political Thought, Middlesex, Penguin Books, 1985, p. 26.

${ }_{16}$ Both authors base their considerations of politics and history on specific notion of experience related to the acting and suffering of human beings. In Arendt, "all thought arises out of experience” (Hannah Arendt, “On Hannah Arendt”, in M. Hill (ed.), Hannah Arendt and the Recovery of the Public World, New York, St. Martin's Press, 1979, p. 308). For Koselleck too, history is basically Erfahrungswissenschaft, the "science of experience," and deals with the experiences and expectations of those who act and suffer (Reinhart Koselleck, Futures Past: on the Semantics of Historical Time, New York, Columbia University Press, 2004, p. 256). On the notion of experience in both authors, $c f$. Hoffman; specifically re- 
encounter with the totalitarian rule of the $20^{\text {th }}$ century. After experiencing shock in the face of the atrocities committed by the German Nazi regime, she pointed to the difficulty in understanding totalitarian institutions with the means and concepts that were available in the social and political sciences. Her questions were: What kind of government is this? How to understand it? Do we have appropriate categories that can help us to think about it? The central phenomenon that prompted her thinking and attempt at an understanding (Begreifen) was the totalitarian institution of the extermination camp. ${ }^{17}$ For Arendt, its organisation with the inversion of law and the total loss of meaning represents an ultimate novelty that marks the factual break in the Western political tradition. It provides a negative starting point for her questioning of political concepts. In the way this institution was set up, not only some groups became superfluous and were exterminated, but the human condition and crucial capacities themselves were at stake, such as plurality and capacity for action. That is why she considered such total domination to be "unprecedented", in spite of the fact that phenomena had previously existed that were similar and contained the elements that could lead thereto (such as colonial violence, racism, eugenics, genocide, etc.). Arendt noticed that, while the whole program of extermination involved an insane consistency, it could not be understood with the help of the given concepts and categories - that is to say, it eluded conceptualisations. It therefore represents the ultimate challenge to the social and political sciences and induces not only a crisis of understanding, but a crisis of the existing theories. While representing a "questionable accumulation of tradition," the avail-

garding Koselleck, $c f$. Gennaro Imbriano, Der Begriff der Politik. Die Moderne als Krisenzeit im Werk von Reihart Koselleck, Frankfurt and New York, Campus Velag, 2018, specifically regarding Arendt, $c f$. Hyvönen, "The Janus face of political experience”; and Jonas Holst, "Retrieving Experience: On the Phenomenology of Experience in Hegel and Kierkegaard, Arendt and Gadamer”, Open Philosophy, 2 (2019), pp. 480-490.

17 Arendt differentiated between concentration and extermination camps, which she considered "the most extreme form of concentration camps." Concentration camps "existed long before totalitarianism made them the central institution of government," and their specific was that they were not penal institutions intended for people who committed crime. Their inmates were those who "were deprived of their judicial person." This deprivation of the status was already the first step towards extermination which, according to Arendt, "happens to human beings who for all practical purposes are already 'dead'.” Hannah Arendt, Essays in Understanding, New York, San Diego and London, Harcourt Brace \& Company, 1994, p. 236. Cf. Hannah Arendt, Origins of Totalitarianism, London, André Deutsch, 1986, p. 286, pp. 300-302, pp. 437-459. 
able political concepts (i.e. of power, authority, violence, etc.) start concealing instead of revealing the new phenomena and events..$^{18}$

The reasons for this are twofold. First, there is a problem understanding what politics and the political were considered in the past, and what they became in the modern world - and this is connected with the way the whole tradition of Western political thought deals with political phenomena and events, while observing them from the point of view of the philosophical spectator (from Plato to Marx). That includes the question of whether the Western concepts of politics still reflect political experiences at all, or are just empty shells, and whether politics, from the point of view of political philosophy and the factual experience of extreme political violence in the $20^{\text {th }}$ century could still be deemed to be an activity that can claim any meaning. ${ }^{19}$ The break in tradition therefore took place in political philosophy, and in real history, while it is reflected in the crisis of conceptuality as well.

In political thinking, the break was, on the one hand, epitomised by those theories that turn the philosophical concept of the political (and historical) into the activity of social progress. Arendt devotes attention to the fact that traditional Western political thought very early turned away from the world of human affairs into the philosophical vita contemplativa and refused to take into account human plurality and the human potential for action - while modern philosophers returned to the political experience gained in the time of modern revolutions. That is why she deems Hegel's philosophy to be the most important consequence of the French Revolution and Hegel to be the author who "actually broke with the tradition, because he was the first thinker to take history [as a realm of human affairs, remark added by V.J.] seriously, that is, as yielding truth." ${ }^{20}$ Meanwhile, when elaborating on the event of the French and subsequent revolutions, modern thinkers have again, according to Arendt, taken a step away from the concrete experiences of the acting people and revived the

18 For more on this, see Vlasta Jalušič, "Les éléments de la tradition en question: Hannah Arendt en ex-Yugoslavie et dans les États successeurs”, Tumultes, 8 (30/2008), pp. 81-106. Cf. Arendt's early essays in German: Hannah Arendt, Fragwürdige Traditionsbestände in politischen Denken der Gegenwart: vier Essays, Frankfurt, Europäische Verlagsanstalt, 1957.

19 Hannah Arendt, The Promise of Politics, New York, Schocken Books, 2005, pp. 93-204.

20 Hannah Arendt, The Life of the Mind. Vols. I \& II, New York, Brace \& Jovanovich, 1978, Vol. II, p. 45 . 
philosophical concept of the political. The result was the invention of the concept of world history as a single process in the philosophy of history, whereby they attempted to find "the law of history". This resulted in thinking about history in terms of (accelerated) processes and (social) progress.

Arendt therefore writes about several breaks: a) the gap that always existed between the past and the future as the existential human condition; b) the break that arose in the $18^{\text {th }}$ century with modern political philosophy (already announced earlier by Machiavelli's political thinking) and took place in the occidental tradition together with the event of the modern revolutions (expressed in Hegel's philosophy); c) $19^{\text {th }}$ century philosophy's break with authority, traditional values, and religion (in the works of Marx, Nietzsche, and Kierkegaard); and d) the break embodied by the $20^{\text {th }}$-century totalitarian event that she considered to be the "final" rupture and therefore the ultimate crisis. This last break can no longer be bridged by means of traditional concepts; it is irreparable and has become a tangible reality, an experience of confusion for everyone and therefore a politically relevant fact as well. ${ }^{21}$ If politics, the state and its institutions, and so on, are capable of causing such horrors, and if the citizens are ready to participate, watching and/or ignoring it, what sense can these institutions make for the community at all? ${ }^{22}$ How can people arrange political forms of living together after such break?

According to Arendt, this burden is the predicament of our time represented in the conceptual and political crisis, which will not disappear but remain with us. ${ }^{23}$ This is not only a negative sign, but an opportunity as well, as it lays bare

${ }^{21}$ Arendt, Between Past and Future. She discusses the breaks in several other texts. i.e. The Origins of Totalitarianism, On Revolution, and Hannah Arendt, "Karl Marx and the Tradition of Western Political Thought”, Social Research, 69 (2/2002), pp. 273-319, to mention just a few.

22 Arendt, The Promise of Politics.

23 Jerome Kohn, "Introduction", in Arendt, Essays in Understanding, p. xv. Cf. also Jakob Norberg, "Arendt in Crisis: Political Thought Between Past and Future", College Literature, 38 (1/2011), pp. 131-149. Not only Arendt, but also several other thinkers such as Walter Benjamin and Theodor $\mathrm{W}$. Adorno noted that the $20^{\text {th }}$ century wars and the emergence of totalitarianism with its culmination in Auschwitz represented a breaking point in history ( $c f$. Barros, "Perspectiva sobe o tempo em Hannah Arendt e Koselleck", p. 185) and revealed problems that are inherent to Western modernity. Arendt, however, linked this break with the need to rethink how the whole tradition conceptualised politics and human action. 
the automatic assumptions of the social sciences: "Every science is necessarily based upon a few inarticulate, elementary, and axiomatic assumptions which are exposed and exploded only when confronted with altogether unexpected phenomena which can no longer be understood within the framework of its categories.”24 For Arendt, the contemporary (conceptual) thinking about politics and existing institutions therefore needs to start from this rupture in the present and attempt to proceed "without banisters" (of tradition). It is worth noting here that Hannah Arendt - although she claimed that the tradition of political philosophy is responsible for our understanding of politics and political concepts (because it did not take seriously their key dimension of human action) - in her attempt to understand total domination focused primarily on concrete social and political analysis. This means, on the study of actual structures of power, apparatuses of rule, rather than deriving conclusions from theoretical models. ${ }^{25}$

\section{Crisis, revolutions, and modern conceptuality}

What in Arendt occurs as the rupture between past and future is represented in Koselleck by the phenomenon of crisis. Crisis originally implies a temporal dimension, and thus becomes a concept which, "in modern times, implicitly expressed a theory of time." ${ }^{26}$ Moreover, crisis is one of the central concepts through which modern political conceptuality started to develop in the time between the $18^{\text {th }}$ and $19^{\text {th }}$ centuries (the so-called Sattelzeit), when the modern concept of time was born: "Crisis directs itself, as it were, toward the necessity of time to make itself comprehensible as a concept." ${ }^{27}$

In classical thought, crisis was connected with several domains (originating from medicine) and became a figurative expression for various kinds of uncertainty, risk, and the absence of continuity, which would provide a basis for explaining new events. With the Neuzeit, the concept becomes (together with some other sets of concepts) generalised and starts to crucially define an entire

24 Arendt, Essays in Understanding, p. 232.

25 Cf. Arendt, Between Past and Future, p. 98.

26 Reinhart Koselleck, "Remarks on the History of the Concept of Crisis", in R. Lilly and J. Sallis (eds.), The Ancients and the Moderns, Indiana University Press, Bloomington, 1996, p. 149.

27 Ibid. 
epoch and its events. Crisis articulates a growing consciousness of the existential difference between the way the world is experienced, and the expectations through which our intentions and anticipations about the world are formulated. ${ }^{28}$ Despite the fact that this is a universal condition of active human agents, the gap between the experienced (past) and the expected (future) becomes even more pronounced during revolutions. To underline the situation of such a crisis of tradition, where one is all of a sudden confronted with an absolute novelty, Koselleck refers to the times of modern revolutions and cites Tocqueville: "I go back from age to age up to the remotest antiquity, but I find no parallel to what is occurring before my eyes; as the past has ceased to throw its light upon the future, the mind of man wanders in obscurity." 29 [Italics added by V. J.]

Arendt uses the same sentences of Tocqueville to emphasise the feeling of an absolute novelty and the rupture in historical time that occurred with the modern revolutions and the emergence of the concept of history. For both Arendt and Koselleck, revolution represents the key to understanding the modern experience of politics, history, and also to the novel perception of temporality. Like Arendt, Koselleck considers it a novelty that cannot be compared to any previous political event in written history. The keyword "revolution" represents a paradigmatic example for his study of the history of concepts (in addition to the very concept of "history") and it stands in his work as a kind of basis for his later monumental project Geschichtliche Grundbegriffe..$^{30}$ In his elaboration of the notion of revolution, Koselleck relies on several authors, but also specifically refers to the book On Revolution by Hannah Arendt. ${ }^{31} \mathrm{He}$ too - like Arendt - summarises Karl Griewank's extensive study on the modern concept of revolution. ${ }^{22}$ Despite the fact that they both proceed from the same moment of the break in

28 Koselleck, Futures Past, p. 257.

29 Alexis de Tocqueville, On Democracy in America, cited in Koselleck, Futures Past, p. 31. These sentences are cited many times by both Hannah Arendt and Reinhart Koselleck when dealing with the phenomena and concept of time after the modern revolutions and the question of the tradition of political and historical thought. Arendt quotes it in her works On Revolution, Between Past and Future, The Life of the Mind, and Koselleck in Vergangene Zukunft (Futures Past) and Geschichtliche Grundbegriffe.

3o Cf. Olsen, Beyond utopianism and relativism, p. $172 \mathrm{ff}$.

31 Hannah Arendt, On Revolution, Penguin Books, Harmondsworth, Middlesex, 1990.

32 Karl Griewank, Der neuzeitliche Revolutionsbegriff: Entstehung und Entwicklung, Weimar, Hermann Böhlaus Nachfolger, 1955. 
tradition (and the crisis that accompanies it), the understanding of this break and the role of the modern revolutions in it is different for each of the authors.

Koselleck treats the concept of revolution in the broader context of his conceptual investigations and connects it to a large extent with the results of his early reflection on the crisis. ${ }^{33}$ There he attempted to explain the reasons for the crisis and therefore the rupture that occurred between the $18^{\text {th }}$ and $19^{\text {th }}$ centuries and which, according to him, continues to the present day. One of the key findings is that the deep crisis that took shape in the $18^{\text {th }}$ and $19^{\text {th }}$ centuries fuelled the tensions that arose within the absolutist state (from his viewpoint, already a typical modern state that pacified religious wars and introduced the principle of moral and religious neutrality, by which it dug its own grave, so to speak). It produced bourgeois society, understood as the "new world" and having global aspirations, while at the same time denying the old world, i.e. the absolutist state and its neutrality. The key political question of whether the apparatus of absolutism and its sovereign ruler will continue to rule, or whether the bourgeoisie of the new society will rule, is resolved by a revolution. Koselleck identifies two epochal events at the beginning and end of classical absolutism: at the beginning there were the religious civil wars that this state pacified, and at the end there was a different civil war, the French Revolution, which brought an end to the absolutist state. ${ }^{34}$ The process of secularisation thus led to a specific dialectic, disastrous for the absolutist state. It was only with this event that the crisis became a constant companion of the modern age, and that European history, by pulling the whole world into a state of permanent crisis, became world history. In later writings, Koselleck analyses this spread and interaction of events in Europe and globally with Bloch's words: Gleichzeitigkeit der Ungleichzeitigkeiten (the simultaneity of the non-simultaneousnesses).35

In this constellation, a world of politics that is separated from morality becomes a constant object of criticism and, according to Koselleck, practically redundant. It is replaced by the critique developed by the philosophy of history and

33 Reinhart Koselleck, Kritik und Krise: Ein Beitrag zur Pathogenese der Bürgerlichen Welt, Munich, Pieper, 1973/1959. Cf. also Andrew Simon Gilbert, The Crisis Paradigm. Description and Prescription in Social and Political Theory, Cham, Palgrave Macmillan, 2019, pp. 61-103.

34 Ibid., p. 11.

35 Olsen, Beyond utopianism and relativism, p. 159. 
the constant revolutionisation of consciousness, and this becomes fatal to the political way of reasoning. This type of utopian political thought, due to a break in time, focuses on the future, and the imagined future increasingly begins to determine the way in which the political experience and thinking of the present takes place. ${ }^{36}$

Based on the split between politics (the corrupt absolutist state) and morality (the Enlightenment's philosophy of history, representing the ideology of the rising bourgeoisie), a specific "dialectic of the Enlightenment" and new historical and political terminology formed. Koselleck sees a connection between the critique of the Enlightenment that emerged and the growing crisis, and underlines that the critics were unaware of this connection: it was hidden from them in "images of the future" of the philosophy of history and the vision of the "single" history they adopted. The view of the possibility of a political solution to the crisis is therefore blurred: what obscures it is the Enlightenment concept itself. For Koselleck, therefore, the turning point that occurs with his version of the break in tradition represents the beginning of a kind of "ideal-type" of development that takes place from the Enlightenment and French Revolution onwards. ${ }^{37}$ It is a historical movement of modernity, which only intensifies in the $19^{\text {th }}$ century. Its characteristic is a critique with an exaggerated focus on the future, which produces the historical philosophical concepts which he later describes as Bewegungsbegriffe (movement concepts) such as "emancipation", "freedom", "revolution", and also "history". They are, on the one hand, connected with the idea that history and human development can be controlled and, on the other, with the belief in progress which went together with the then technological developments and the experience of temporal acceleration whereby experience and expectation increasingly diverge.

Koselleck understands this trend as dangerous and irresponsible political thought. He criticises political utopias due to their Politikunfähigkeit (inability for politics). ${ }^{38}$ By focusing on the future, this "moralising" thought devalues the political present. He is also a sharp critic of the normativism of political theory,

\footnotetext{
36 "In the crossfire of criticism, not only was the then current politics worn down, but in the same process politics itself, also politics as a constant task of human existence, dissolved itself into utopian future constructions." Ibid., p. 9.

37 Olsen, Beyond utopianism and relativism, p. 98.

38 Huhnholz, Von Carl Schmitt zu Hannah Arendt?, p. 8.
} 
which, according to him, makes a decisive contribution to pushing politics as an activity to the sidelines. From a different point of view, Koselleck then develops his conception of history as an open course that presupposes actors who contribute to its diversity, which consists of unpredictable elements. History cannot be "made" according to desires and utopian scenarios, but can only be "history in the plural." ${ }^{39}$

Arendt too, writes unfavourably about the philosophy of history, its "depoliticising" core and projections of world history developments - but not for the same reason as Koselleck. While being critical of projections of the philosophy of history and their utopian character, she maintains that, after the rediscovery of the human capacity for action in the French Revolution, the philosophers again turned away from the political experience. The event of revolution marks for her a different turning point regarding politics. She closely analyses several revolutions and discovers in them a temporary disclosure of politics and specific original political forms of power which usually disappear and which the spectator's gaze attempts to suppress ("the lost treasure").

Differently than Arendt, Koselleck remains profoundly critical/suspicious of any political revolution and rather rejects it as a civil war (with the necessary element of violence in it) - and instead further explores and re-describes other different uses of the concept..$^{40}$ Arendt re-describes revolution as a specific experience of action "in concert" and with a political foundation, and thus conceptualises it differently than other revolutionary thinkers (e.g. Marx, whom she sharply critiques). She warns against anti-political interpretations of revolution as merely a fight for power, and therefore civil war and violence.

This not only indicates the different attitude towards the concept and elaboration of the experience of revolution in both authors, but also a different understanding of political action and politics. While Koselleck understands revolution (in accordance with his analysis in Kritik und Krise) as occupying and the withering away of the state and politics, ${ }^{41}$ Arendt sees the possibility of such

39 See Koselleck, “On the disposability of history”, in Futures Past, pp. 193-204, cf. Olsen, Beyond utopianism and relativism.

$4^{0}$ Koselleck, "Historical criteria of the modern concept of revolution", in Futures Past, pp. 43-57.

${ }^{41}$ Cf. Koselleck, Kritik und Krise, p. 101. 
development only if revolution fails in the foundation of a new political constitution and for this reason takes the course of violence and ends up in terror. For her, revolutions are basically the foundations of new political communities (guaranteeing freedom) by acting in concert.

As a final point concerning thinking the break and crisis in both authors, it should be noted that Koselleck, unlike Arendt, and like many of his academic contemporaries in Germany, did not devote himself to research on war crimes, the Holocaust, and concentration camps until the 1970s. This perspective appeared only in his later work and is connected with his study of the dreams in concentration camps, researched by Hannah Arendt's close friend Charlotte Beradt. ${ }^{42} \mathrm{His}$ reflections turn out to be similar to Arendt's, at times even expressed in similar words; he speaks, for example, of a "loss of reality". Koselleck, like Arendt, maintains that the experience of terror cannot (really) be understood and sufficiently explained with the usual (causal) means and categories of interpretation. Due to the absurdity, extreme suffering, and loss of meaning experienced by the victims of terror, he, too, saw the Holocaust as a radical break in history which poses new, perhaps enormous, challenges to understanding and interpreting these experiences. Addressing this break by Koselleck could therefore, according to Olsen, be understood as a new Sattelzeit. ${ }^{43}$

\section{Begreifen}

"To think history, remains a challenge, understanding (Begreifen) will always force us to rethink." 44

Arendt and Koselleck relate their notion of concept (Begriff) to "understanding/ comprehension" - and it is through this approach that their political and historical concepts are bound to the worldly (political and social) experiences. In

42 Charlotte Beradt, Das Dritte Reich des Traums; mit einem Nachwort von Reinhart Koselleck, Frankfurt, Suhrkamp, 1981. Cf. Koselleck, “Terror and Dream. Methodological Remarks on the Experience of Time During the Third Reich", in Futures Past, pp. 205-221.

43 Cf. Olsen, Beyond utopianism and relativism, pp. 265, 268.

44 Cf. Reinhart Koselleck, "Begriffliche Innovationen der Aufklärungssprache”, in R. Koselleck, U. Spree, and W. Steinmetz (eds.), Begriffsgeschichten: Studien zur Semantik und Pragmatik der historischen und sozialen Sprache, Frankfurt, Suhrkamp, 2006, pp. 309-339, cited after Christian Geulen, "Reply", Contributions to the History of Concepts, 7 (1/2012), p. 118. 
German, they both use the term begreifen (to grasp) for what in English usually entails "to comprehend" or "to conceive". Yet the meaning of the concept of Begreifen gets lost in translation, especially its link to experience, if it is translated as "conceiving" while it is closer to "grasping" (Be-greifen). 45 What does the concept of Begreifen mean?

Arendt explains her basic notion of Begreifen that frames her "method" of political thinking in several texts, but the account is particularly condensed in the introduction to the Origins of Totalitarianism. It is closely related to her question of where one should start to think after the experience of the break in tradition, resulting in total domination and terror. She writes:

Comprehension (Begreifen) does not mean denying the outrageous, deducing the unprecedented from precedents, or explaining phenomena by such analogies and generalities that the impact of reality and the shock of experience are no longer felt. It means, rather, examining and bearing consciously the burden which our century has placed on us - neither denying its existence nor submitting meekly to its weight. Comprehension, in short, means the unpremeditated, attentive facing up to, and resisting of, reality - whatever it may be. ${ }^{46}$

This explanation corresponds to what she said in different ways in several published texts and in her series of lectures "The Great Tradition and the Nature of Totalitarianism", ${ }^{47}$ the topic which became her main task when attempting to explain and differentiate the novelty of total domination (as she saw it) from tyranny. As stated above, Arendt's predicament was how to understand/conceptualise the novel phenomenon of total domination, which has, in her opinion, caused "the explosion of categories of thought and standards of judgement." Therefore, her main question was: "Where can appropriate categories be found to understand the nature of totalitarianism?" And her answer: "To understand the new form of government we have to understand anew, in the light of our

45 Cf. Geulen, ibid., Elías José Palti, "Reinhart Koselleck: His Concept of the Concept and Neo-Kantianism”, Contributions to the History of Concepts, 6 (2/2011), pp. 1-20.

46 Arendt, Origins of Totalitarianism, p. viii.

47 Some of them are published in Arendt, Essays in Understanding; $c f$. Hannah Arendt, "The Great Tradition and the Nature of Totalitarianism”, $1^{\text {st }}$ lecture, New York, New School for Social Research, 1953 (Series: Speeches and Writings File, 1923-1975). 
experience, the traditional forms and the experiences which they express. Experience of living together, of Men, not Man." ${ }^{\text {48 }}$

In Between Past and Future and some other essays, Arendt presented her blueprint for understanding concepts as exercises in thinking that are strictly bound to events and phenomena in crisis (e.g. the crisis of education or culture, subsequently also the Crisis of the Republic). In The Life of the Mind she further worked on the notion of Begreifen from the perspective of thinking, willing, and judging - while asking the question of whether thinking could prevent evildoing - such as happened in the terror of a totalitarian regime. Concepts as "thought things" need to have the potential to find out the "sense" (Sinn, meaning ${ }^{49}$ of the matter and not just describe what and how a thing functions, etc. All concepts are linked to specific experiences and proceed therefrom (either worldly and sensible or the experience of thinking and understanding), and while they at the same time go beyond it, they also need to be referred back to it - in a different setting.

As the experience of action has special importance in Arendt's thought, her understanding - and therefore conceptualisation - of politics is in fact tied to it: one needs to take into account those particular moments in which politics as human action takes place. These events cannot be seen as "objects" of thought, but rather as temporal phenomena that appear as constituted by both those who are involved in them as well as by the "observers", those who are interested in political events and think, judge, and, finally, write about them. Therefore, political and historical science (both being closely related) are not merely "objective" sciences, but always already condition and "frame" political events both by narration about them and by their former conceptualisations. Thereby, they are in fact a part of the political phenomena. Arendt distinguishes between objectivity and impartiality. For her, political thinking, political science as she called it, is not just an "objective" weighing of events or measuring them according to pre-given concepts, but understanding and judging, which is never blindly bound to the existing criteria. It always to a certain extent "participates" in and belongs to the phenomenal nature of politics.50

\footnotetext{
48 Ibid.

49 Sinn is usually translated into English as meaning, yet it relates to sense and senses.

50 Cf. Vollrath, "Hannah Arendt and the Method of Political Thinking”.
} 
Arendt's notion of Begreifen is therefore specific: it is linked to formal conceptual questions, on the one hand, while on the other it is closely tied to rethinking concepts/events from the perspective of a specific experience. It is non-causal and inevitably linked to the capacity of imagination, which always comes to the forefront when we attempt to understand the actions and suffering of others (we can "think with" others and so practice what Arendt calls, with Kant, an enlarged mentality). Imagination helps us in "bridging the abyss" to others and is "part of the dialogue of understanding" while enabling us "to see things in their proper perspective." ${ }^{11}$ Koselleck too - most vividly when writing on terror and dreams - underlines the role of the historian's imagination, who, in attempting to understand terror in the Third Reich, needs to use the means of fiction and not causal thinking or drawing on analogies..$^{52}$

Political concepts need to disclose and re-construct the Sinn/meaning of a concrete event. If we look at one of the most difficult political concepts, the very concept of the political and politics, then understanding (Begreifen), if we follow Arendt, is definitely not a matter of establishing "truth" but of asking a question of Sinn/meaning (which is always temporal and concrete). Arendt, in her planned but never finalised book on politics (Introduction to Politics), looked into the Sinn/meaning of politics and not the "concept" of "the political" although she reproaches the political tradition with never having a "concept" of the political due to thinking of Man in the singular and not the plural. ${ }^{53} \mathrm{In}$ this respect, Arendt's consideration is radically different from, for example, C. Schmitt advocating for the "essence" of the concept of the political, in which he then finds an emptied form of the "original" conflict between friend and foe, which is constantly repeated in various forms throughout history.

For Koselleck, concepts do not precede the way they appear in reality and are not defined a priori, without a link to the concrete, historical predicates that are attributed to them in concrete circumstances - therefore to what he terms "experience". Concept, differently than "idea", always contains a plurality of content..$^{54}$

\footnotetext{
Arendt, Essays in Understanding, p. 323.

Koselleck, "Terror and Dream”.

Arendt, Introduction to Politics.

Ibid., p. 11.
} 
A word can get one meaning [eindeutig] because it has many meanings [mehrdeutig]. A concept, on the contrary, must retain multiple meanings in order to be able to be a concept. The concept is tied to a word, but it is at the same time more than the word. According to our method, a word becomes a concept, when the full richness of social and political context of meaning, in which, and for which, a word is used, is condensed into one word. ${ }^{55}$ [Translation by V.J.]

This description clearly shows Koselleck's distance from the legacy of the school of the history of ideas. Against the aporia between the clear content of the concept that enables an unambiguous definition and its changing discursive positioning within historical time, Koselleck accepted Nietzsche's maxim that "all concepts escape definition that summarize semiotically an entire process; only that which has no history is definable." ${ }^{56}$ While they do not endure definition, concepts still - through their differentiation - bring about a certain unity of sense, and can, once they are generated, also be broadly employed and generalised. Through such process of differentiation, Koselleck arrives at a series of basic concepts and counter-concepts that are "purified" of sensuality and immediacy and are brought to a certain generality. ${ }^{57}$

For Arendt too, concepts are not definitions but reflect "living” judgements. To think conceptually is to differentiate. In The Life of the Mind she points to the fact that - from the perspective of thinking - concepts are linked to questions that arise out of lived experience. They refer, for example, to "What do we mean when we use this class of words, later called 'concepts"' - such as friendship, knowledge, courage, justice, etc..$^{8}$ With the help of the "answer of Socrates," she describes these concepts as "part and parcel of our everyday speech," yet "the most difficult for the mind to comprehend." 59 They get slippery when one attempts to define them, and their meaning is by no means stable. In fact, concepts are manifestations of thinking. When they are written down and defined,

55 Reinhart Koselleck, “Einleitung”, in O. Brunner, W. Conze, and R. Koselleck (eds.), Geschichtliche Grundbegriffe. Historisches Lexikon zur politisch-sozialen Sprache in Deutschland, Vol. 1, Stuttgart, Ernst Klett Verlag, 1972, p. XXII; see also Koselleck, Futures Past, p. 85.

${ }_{56}$ Koselleck, "Einleitung”, p. XXIII; Koselleck, Futures Past, p. 84, cf. Palti, "Reinhart Koselleck”, p. 7 .

57 This still shows a considerable similarity with C. Schmitt's approach to concepts.

${ }_{58}$ Arendt, The Life of the Mind, Vol. I, p. 166.

59 Ibid., p. 176. 
so that common opinion gets hold of them, they might become mere results of cognition - no longer related to experience, and therefore need to be treated in the light of new experience. When referring to language, Arendt writes: "All philosophical terms are metaphors, frozen analogies as it were, whose true meaning discloses itself when we dissolve the term into the original context."

As stated by Palti, concept in Koselleck is "nothing but the very semantic web woven through the series of its changing definitions, which are deposited in it and become reactivated in the present uses of that concept." ${ }^{61}$ While they have a contingent nature, concepts contain historical experience, and can, therefore, "make" concrete actions meaningful. They articulate and connect living experiences (and expectations) and also create new meanings. In order to grasp and think through long-term processes, conceptual history must therefore distance itself from social history. Concepts are "indexes of structural transformations" and retrospectively also "indexes of transformation in social experience." ${ }^{\prime 2}$ Koselleck, like Arendt, avoided Geistesgeschichte either in the form of a history of ideas or in the form of a mirror history of material processes. His focus was the experience condensed in concepts and the theory invested therein. ${ }^{63}$

Both Arendt and Koselleck are (their criticism of philosophy of history notwithstanding) to a certain extent Hegelians when it comes to thinking of concepts and understanding/Begreifen. ${ }^{64}$ Yet they are critical of any "system" and the immanent meaning contained in history, even if it discloses itself as a (dialectical) process. ${ }^{65}$ The question they attempt to answer is: How can anything new in history emerge at all if there is pre-stabilised, also conceptual, harmony? How can

${ }_{61}$ Palti, "Reinhart Koselleck", p. 11.

62 Ibid., p. 9.

${ }_{63}$ "That the history is condensed/sedimented [niederschlägt] in specific concepts and it only becomes history in the ways it is grasped/understood/conceptualised at the time [wie sie jeweils begriffen wird] is the theoretical premise of the historical method that we use here." Koselleck, “Einleitung”, p. XXIII [Translation 'compiled' by V. J.]

${ }_{64}$ I do not have space for further discussion of this within the framework of this text. For an elaboration of Koselleck's concept of the concept of Hegel and neo-Kantianism, see Palti, "Reinhart Koselleck”. For the Arendt-Hegel constellations, see Vlasta Jalušič, "G.W.F. Hegel”, in W. Heuer et al. (eds.), Arendt-Handbuch. Leben - Werk - Wirkung, Stuttgart / Weimar, Metzler, 2011, pp. 216-221.

65 Arendt, The Life of the Mind. Vol. II. B, pp. 39-51. 
we understand (begreifen) that we are dealing with something new? For Arendt, this is only possible if we take into account the ability of humans to begin anew as a political capacity. For Koselleck, history represents a human "product" which is an open and contingent process and not a construction drawn by a transcendent demiurge. ${ }^{66}$

\section{Crisis as a crisis and a moment to understand}

"For whenever in our own century revolutions appeared on the scene of politics, they were seen in images drawn from the course of the French Revolution, comprehended in concepts coined by spectators, and understood in terms of historical necessity." 67

Koselleck sees the origins of "movement concepts" such as revolution, emancipation, freedom, history, etc., in the modern rupture between the space of experience and the horizon of expectation. These concepts, which are the result of a crisis, at the same time constantly generate it. The horizon of expectation, which is critical and moral at the same time, produces an anti-political effect and has a share in the "acceleration" of history and real time. The crisis reveals the impossibility of formulating a politics that would meet the real challenges. Arendt takes a step further and asks why philosophers and historians tend to construct anti-political concepts and think either in terms of analogies or in categories that (no longer) correspond to actual (political) experience. Koselleck's answer to this would probably be that they escape to the realm of morality (critique), ignore political experience, and with utopian thinking further increase the rupture between experience and expectation. Arendt's answer is that they jump into theory, a world that is elevated above politics and observed from Archimedes' point, and then they judge politics according to their theoretical or philosophical criteria - coming from the experience of thinking, not acting. They want to regulate the world from the point of view of the will - which reaches into the future and subsumes the concept of politics based on the model of ruling and ruled (in Koselleck's case, this would be essentially normative and therefore "moral” and not political).

\footnotetext{
66 Palti, "Reinhart Koselleck", p. 12.

${ }_{67}$ Arendt, On Revolution, p. 56.
} 
Both authors, therefore, question the responsibility of those who think of history, politics, and human agency, and discuss concepts. Koselleck, like Arendt, argues that thinkers who pursued a moral argument had no concept of politics, and that they contributed to the "incapacity for politics." He also addresses the critique of the Enlightenment philosophy of history to all those who subsequently, for example in the revolutionary tradition, perceived themselves as initiated into the laws of revolution, understood as a self-accelerating process (of history). They pursued, according to Koselleck, a conscious aspiration for leadership. ${ }^{68}$ In other respects, he criticises the attitude of those who believe that it is possible to "make history" as something available and shows how well the historian Marx (in Ludwig Bonaparte's $18^{\text {th }}$ Brumaire) understood the limits of the possibility of "making" history while he was shifting the horizon of expectation ever further into the future. ${ }^{69}$

Arendt too, criticises philosophers of will who attempt to rule instead of thinking. For her, the two different spheres of human experience (one arising from human action, the other from thinking) lead to two entirely different conceptualisations of politics. Arendt sets out to explore these experiences and the implications that they have for political thinking and action. The first is the recurring experience of acting people (who live through it spontaneously, at times when they act together), from which in history, according to Arendt, there always arise anew specific forms of power - and in On Revolution she shows this in the case of the councils. However, they - like a lost treasure - usually sink into oblivion. This decline is greatly aided by another experience, which conceptualises politics on the model of philosophical and/or philosophical-historical thinking. The thinkers who wrote of modern revolutions mainly did not create new concepts according to the political experience of the joint actions of plural people, but relied on the old ones, and restored, adapted, and redefined them under the conditions of a "broken" tradition (for example, the concept of revolution, the concept of authority). This is, according to Arendt, one of the reasons why the experience of the French Revolution repeats itself as if it were a general experience of revolution - through the produced conceptual frameworks of necessity, violence, and terror - and why revolution is rejected as automatic violence rather than political action that can create stable political communities in the

\footnotetext{
68 Koselleck, Futures Past, p. 54.

69 Ibid., pp. 201-202.
} 
long run. The past experience of the joint actions of plural actors is not "immortalised" in memory through appropriate concepts, but is replaced by the results of the activities of observers-philosophers: it therefore appears as the result of (individual or collective) will and decisionism, whereby the stronger or weaker conflict of (sovereign) wills results in eventual conflict resolution/pacification. The meaning (not goal!) of politics is not freedom, it is rather understood as a means of ruling, governing, and managing "crises" (an oxymoron according to the original concept of crisis).

Koselleck's perception of politics is, as I noted earlier, substantially different from that of Arendt. While she understands politics as the joint action of equals, Koselleck, who proceeded from Schmitt's understanding of "the political", nevertheless relies on the original meaning of crisis and conflict. Even though he, through a specific anthropology, which he conceives as a condition for any history, ${ }^{70}$ later forms a similar "basis" as Arendt in The Human Condition, ${ }^{71}$ he nonetheless establishes a binary (and not plural) structure of the human situation..$^{72} \mathrm{He}$ departs from Schmitt's essential conflict structure of the political and transforms it from the Begriff des Politischen (concept of the political) into the Begriff der Politik (concept of politics). ${ }^{73}$ Despite the emphasis on human action and plurality, he sees politics primarily as an original split, crisis, and conflict $^{74}$ (as opposed to utopian projections of movement concepts). In order to achieve what is important to the community in the present, the political reconciliation of conflicts and realistic expectations are required. Palonen insists that it is precisely the preservation of variability, plurality, and conflict that is the key to Koselleck's temporal perception of concepts. This also makes it possible to understand conceptual change, rather than a kind of "anthropology" in spatial terms. He argues that besides Heidegger and Schmitt, Arendt too relies on anthropology and ontology, but not so Koselleck, who introduces the tempo-

\footnotetext{
Cf. Imbriano, Der Begriff der Politik; Olsen, Beyond utopianism and relativism, p. 74.

Cf. Hoffman, "Koselleck, Arendt, and the Anthropology of Historical Experience".

Cf. Janet Coleman, "The Practical Use of Begriffsgeschichte”, Finnish Yearbook of Political Thought, 3 (1/1999), pp. 28-40.

73 Cf. Imbriano, Der Begriff der Politik.

74 Cf. Timo Pankakoski "Conflict, Context, Concreteness: Koselleck and Schmitt on Concepts”, Political Theory, 38 (6/December 2010), pp. 749-779.
} 
rality of concepts rather than spatiality. ${ }^{75}$ However, Arendt's understanding of political phenomena does not imply Palonen's emphasis, as it is by no means any kind of essentialism. Her Sinn (sense) and not the "meaning" (Bedeutung) of politics is temporal, not some eternally present essence. Even when she says that the Sinn of politics (as opposed to the thesis of politics as ruling and being ruled or conflict) is freedom, she adds that "its field of experience is action," so that freedom is not a given in terms of space, but "takes place" only temporarily, when people act together. ${ }^{76}$

That this move was, all the differences notwithstanding, well understood by Koselleck is obvious from his elaboration of Arendt's approach in his Laudatio to Furet, and the connection of his own thinking to these considerations. He emphasised that historical thinking must not abolish the political postulate of freedom: "The political postulate of freedom also has methodological consequences for Histoire [...]. The human being is responsible for the choice of the categories, by means of which s/he disentangles the history. It must be those which are also able to motivate and guide political action." 77

\section{Conclusion: The common thinking space}

Despite the impression that each of them focused on the one main break between the past and the future, Arendt and Koselleck in fact both consider multiple breaks in tradition and not just one. ${ }^{78}$ To repeat, the existential tension between the past and the future (between the space of experience and the horizon of expectation) is a key moment of the human condition for both. For Koselleck, the main conceptual change in modernity occurred with the Sattlezeit, the Enlightenment, and the French Revolution, and was later "supplemented" by the industrial and technological revolution and the "acceleration" of time. Arendt, as well, sees the French Revolution as crucial to Neuzeit and as the advent of the new temporality in which modern political conceptuality was born - yet not

75 Kari Palonen, “The Life and Work of Reinhart Koselleck”, Redescriptions. Yearbook of Political Thought, Conceptual History and Feminist Theory, 16 (1/2013), p. 219.

76 Arendt, Between Past and Future, p. 145.

77 Koselleck, "Laudatio", p. 9, emphasis added by V. J.

78 One can agree with Palti, who problematises the thesis of a single break. Cf. Elias José Palti, An Archaeology of the Political: Regimes of Power from the Seventeenth Century to the Present, New York, Columbia University Press, 2017. 
in accordance with the factual political experiences. Moreover, she too addresses the socio-technological development of the $19^{\text {th }}$ and $20^{\text {th }}$ centuries as leading to the process thinking and acceleration. Her main emphasis, however, is that the onset of totalitarian rule in the $20^{\text {th }}$ century with the creation of extermination camps created a factual and definite break with tradition. While Koselleck at first did not conceive the terror of the concentration camps as another break in tradition, subsequently, in the 1970s, he seemed to join Arendt in thinking about another turning point that occurred with the $2 \mathrm{O}^{\text {th }}$ century terror of the Holocaust.

Arendt's conclusion regarding the "difficulties of understanding" which occur when faced with the factual break in tradition is that one must unveil precisely the "burden" of incomprehensible experiences as the burden of our time. These events are only incomprehensible if the explanation is tied to the methodically constructed theoretical concepts that have lost their link with human capacities (and deeds and misdeeds). Therefore, even if one cannot objectively, by explaining the causal chain, describe concentration camps, one can still attempt to understand them..$^{79}$ It is this "non-communicative" locus comprising the starting point of her thinking from which Arendt develops her specific approach to Begreifen and political concepts. Koselleck comes very close to this when thinking about understanding the experience of concentration camps through dreams. Arendt calls Begreifen a "strange enterprise" that is always an attempt to approach and utter what "is". It is not a theoretical procedure, but, so to speak, "the other side of action," "that form of cognition, distinct from many others, by which acting men (and not men who are engaged in contemplating some progressive or doomed course of history) eventually can come to terms with what irrevocably happened and be reconciled with what unavoidably exists."»o

She addresses the problems with contemporary political concepts not only in terms of the problematic of modernity, but as being inherent in the whole tradition, particularly due to the neglect of plurality, which makes it impossible to think politics from the perspective of active people. That is why the modern (transformed) concepts contain the questionable sediments that became radi-

79 Arendt, Essays in Understanding, p. 302, and Vollrath, "Hannah Arendt and the Method of Political Thinking”, p. 172.

8o Arendt, Essays in Understanding, p. 321-322. 
calised in the totalitarian rule of the $20^{\text {th }}$ century and why their further use hinders an understanding of the new forms of government. ${ }^{81}$

Paradoxically as this may sound, it seems that the thinking of the breaks in time and crisis by these authors, with such different conceptualisations of politics, can complement each other. Koselleck thinks in terms of stable structures that can prevent conflict, war, and so on. Arendt thinks in terms of the formation of such structures, the actions that can establish them, and at the same time about maintaining the capacity to act as the capacity for freedom and peaceful=political interruptions of the seemingly automatic processes of society.

Koselleck's Begreifen is a radical reconsideration of historical thinking and the way we understand history. By determining human experience, plurality, and reciprocity as a condition of the historical process, he highlighted the need to think history and politics together. As Mehring wrote about his last work: "With the 'Begriffsgeschichten', Koselleck makes it clearer than ever before that his theory and method represent a normative and political claim of their own, aiming at a 'grasped history' (begriffene Geschichte), a clear historical picture. With Thucydides, Koselleck argues for a 'redescribing' (Umschreiben) of history: for a re-connection of exaggerated expectations to "experiences" and for historically controlled, justified expectations." ${ }^{82}$

If we look more closely, Arendt, in Between Past and Future, as far as history is concerned, also put it this way. Yet her elaboration of politics may seem more "utopian" in relation to what Koselleck offers us. Given the political experiences she draws upon and which sediment she has found in modern revolutions, she seems to imagine that human beings, who are endowed with the capacity for new beginnings, could strive for more than just "lower expectations" - although there might be times when this is needed as well in order to self-limit the burning revolutionary spirit.

81 Arendt points to the revolutionary movements after WW2, and their understanding of violence, power, authority, and revolution. Cf. Hannah Arendt, On Violence, London, Harvest, 1970.

82 Reinhardt Mehring, “R. Koselleck: Begriffsgeschichten”, H-Soz-Kult, 2006, https://www. hsozkult.de/publicationreview/id/reb-9137, accessed 24 April 2021. 
For Koselleck, who sees politics primarily as a conflict and a dispute (a crisis), and considers revolution to be the multiplication of conflict; the issue is primarily how to calm it down, to ensure stability in the long run, and to link "excessive" expectations to concrete, more "realistic" experiences. It may seem as if Koselleck seeks to bring "morality" (and thus critique) back into politics; yet, not in a way that makes politics moralistic, but in such a way that people are able to make critical judgments about what constitutes "possible" histories and the role of the historian is precisely to open up this horizon. Perhaps this is why Koselleck's "conservative" critique of moral "politics" can be read in parallel with Arendt's critique of "social" and "humanitarian" solutions to political problems (first in the French Revolution), i.e. solutions that can lead to violence. Both are therefore critical of the replacement of politics with morality (which, in their opinion, leads to terror). And they both, each in their own way, strive to achieve political solutions, and thus the "possible" (in politics and history). In short, for them, politics represents both the realisation of human potential (Arendt) and the possibility of formulating common realistic answers to burning questions (possible histories, Koselleck).

While this article cannot even remotely capture the complexity of the conceptual thinking of the two authors considered, I would like to conclude that the conceptual journeys through the breaks and crises on which they developed a distinctive conceptual thinking (Begreifen) - related to many similar questions - are both close and apart at the same time. We can also read Arendt and Koselleck as parallel and complementary authors: what Koselleck pursued in history is emphasised by Arendt in political thinking. Both focused on people's capacity to act and considered to be a key epistemological condition of the historical and/or political thinking of events and concepts, while at the same time linking history and politics into a key common goal: to return the responsibility for actions and concepts to the human sphere.

\section{References}

Arendt, Hannah, "The Great Tradition and the Nature of Totalitarianism", $1^{\text {st }}$ lecture, New York, New School for Social Research 1953 (Series: Speeches and Writings File, 1923-1975), Hannah Arendt Papers at the Library of Congress, https://memory.loc.gov/ cgi-bin/ampage?collId=mharendt\&fileName=05/05145a/05145apage.db\&recNum=0. 
Arendt, Hannah, Fragwürdige Traditionsbestände in politischen Denken der Gegenwart: vier Essays, Frankfurt, Europäische Verlagsanstalt, 1957.

Arendt, Hannah, On Violence, London, Harvest, 1970.

Arendt, Hannah. The Life of the Mind. Vols. I \& II, New York, Brace \& Jovanovich, 1978.

Arendt, Hannah, “On Hannah Arendt”, in M. Hill (ed.), Hannah Arendt and the Recovery of the Public World, New York, St. Martin's Press, 1979, pp. 333-334.

Arendt, Hannah, Between Past and Future: Eight Exercises in Political Thought, Middlesex, Penguin Books, 1985.

Arendt, Hannah, Origins of Totalitarianism, London, André Deutsch, 1986.

Arendt, Hannah, On Revolution, Harmondsworth, Middlesex, Penguin Books, 1990.

Arendt, Hannah, Essays in Understanding, New York, San Diego, London, Harcourt Brace \& Company, 1994 .

Arendt, Hannah, "Karl Marx and the Tradition of Western Political Thought”, Social Research, 69 (2/2002), pp. 273-319.

Arendt, Hannah, The Promise of Politics, New York, Schocken Books 2005.

Barros, José D’Assunção, “Perspectiva sobe o tempo em Hannah Arendt e Koselleck: duas leituras sobre a quebra entre o Presente e o Passado”, Argumentos, 6 (12/2014), pp. 169-189.

Beradt, Charlotte, Das Dritte Reich des Traums; mit einem Nachwort von Reinhart Koselleck, Frankfurt, Suhrkamp, 1981.

Buckler, Steve, Hannah Arendt and Political Theory: Challenging the Tradition, Edinburgh, Edinburgh University Press, 2011.

Brunner, Otto, W. Conze, R. Koselleck (eds.), Geschichtliche Grundbegriffe. Historisches Lexikon zur politisch-sozialen Sprache in Deutschland, Vols. 1-9, Stuttgart, Klett-Cotta, 1972-1997.

Coleman, Janet, “The Practical Use of Begriffsgeschichte”, Finnish Yearbook of Political Thought, 3 (1/1999), pp. 28-40.

Funken, Peter, “Hannah Arendt’s Denkraum: The Experience of an Experimental Exhibition”, 2006, http://www.wolfgang-heuer.com/denkraum/eng/space.htm.

Geulen, Christian, "Reply”, Contributions to the History of Concepts, 7 (1/2012), pp. 118128.

Gilbert, Andrew Simon, The Crisis Paradigm. Description and Prescription in Social and Political Theory, Cham, Palgrave Macmillan, 2019.

Grunenberg, Antonia, “Arendt, Heidegger, Jaspers: Thinking through the Breach in Tradition”, Social Research, 74 (4/2007), Hannah Arendt's Centenary: Political and Philosophical Perspectives, Part II, pp. 1003-1028.

Heuer, Wolfgang, "Verstehen als sichtbarmachen von Erfahrungen", in W. Heuer and I. von der Lühe (eds.), Dichterisch denken: Hannah Arendt und die Künste, Göttingen, Wallstein, 2007, pp. 243-257. 
Hoffman, Stefan-Ludvig. "Koselleck, Arendt, and the Anthropology of Historical Experience”, History and Theory, 49 (2/2010), pp. 212-236.

Holst, Jonas, "Retrieving Experience: On the Phenomenology of Experience in Hegel and Kierkegaard, Arendt and Gadamer”, Open Philosophy (2/2019), pp. 480-490.

Huhnholz, Sebastian, Von Carl Schmitt zu Hannah Arendt? Heidelberger Entstehungsspuren und bundesrepublikanische Liberalisierungsschichten von Reinhart Kosellecks “Kritik und Krise”, Berlin, Duncker \& Humblot, 2019.

Hyvönen, Ari-Elmeri, “The Janus face of political experience”, Arendt Studies (2/2018), pp. $125-147$.

Imbriano, Gennaro, Der Begriff der Politik: Die Moderne als Krisenzeit im Werk von Reihart Koselleck, Frankfurt and New York, Campus Verlag, 2018.

Jalušič, Vlasta, "Les éléments de la tradition en question: Hannah Arendt en ex-Yugoslavie et dans les États successeurs", Tumultes, 30 (8/2008), pp. 81-106.

Jalušič Vlasta, “G.W.F. Hegel”, in W. Heuer et al. (eds.), Arendt-Handbuch. Leben - WerkWirkung, Stuttgart, Weimar, Metzler, 2011, pp. 216-221.

Koselleck, Reinhart, "Einleitung”, in O. Brunner, W. Conze, R. Koselleck (eds.), Geschichtliche Grundbegriffe. Historisches Lexikon zur politisch-sozialen Sprache in Deutschland, Vol. 1, Stuttgart, Ernst Klett Verlag, 1972, pp. XIII-XXVII.

Koselleck, Reinhart, Kritik und Krise. Ein Beitrag zur Pathogenese der Bürgerlichen Welt, Munich, Pieper, 1973/1959.

Koselleck, Reinhart, Sozialgeschichte und Begriffsgeschichte, in W. Schieder \& Sellin V. (eds.), Sozialgeschichte in Deutschland. Vol. 1, Göttingen, Vandenhoek \& Ruprecht, 1986, pp. 89-109.

Koselleck, Reinhart, "Erfahrungswandel und Methodenwechsel. Eine historisch-anthropologische Skizze”, in C. Meier, J. Rüsen J. (eds.), Historische Methode, Munich, Deutscher Taschenbuch Verlag, 1988, pp. 13-61.

Koselleck, Reinhart, "Remarks on the History of the Concept of Crisis”, in R. Lilly, J. Sallis (eds.) The Ancients and the Moderns, Bloomington, Indiana University Press, 1996, pp. 148-158.

Koselleck, Reinhart, “Laudatio auf François Furet”, in Festschrift zur Vergabe des Hannah-Arendt-Preises für politisches Denken an François Furet, Bremen, Heinrich Böll Stiftung, 1996, pp. 9-12.

Koselleck, Reinhart, Futures Past: On the Semantics of Historical Time, New York, Columbia University Press, 2004.

Koselleck, Reinhart, Sediments of Time: On Possible Histories (translation of Zeitschichten), Stanford, Stanford University Press, 2019.

Koselleck, Reinhart, "Begriffliche Innovationen der Aufklärungssprache”, in R. Koselleck, U. Spree, and W. Steinmetz (eds.), Begriffsgeschichten: Studien zur Semantik und Pragmatik der historischen und sozialen Sprache, Frankfurt, Suhrkamp, 2006, pp. 309-339. 
Lara, Maria Pia, The Disclosure of Politics: Struggles Over the Semantics of Secularization, New York, Columbia University Press, 2013.

Mehring, Reinhardt, “R. Koselleck: Begriffsgeschichten”, H-Soz-Kult, 29 November 2006, https://www.hsozkult.de/publicationreview/id/reb-9137.

Norberg, Jakob, “Arendt in Crisis: Political Thought Between Past and Future”, College Literature, 38 (1/2011), pp. 131-149.

Olsen, Nicolas, Beyond utopianism and relativism: History in the plural in the work of Reinhart Koselleck, Florence, European University Institute, 2009.

Palonen, Kari, Die Entzauberung der Begriffe. Das Umschreiben der politischen Begriffe bei Quentin Skinner und Reinhart Koselleck, Münster, LIT Verlag, 2004.

Palonen, Kari, The Struggle with Time: A Conceptual History of 'Politics' as an Activity, Münster, LIT Verlag, 2014.

Palonen, Kari, “The Life and Work of Reinhart Koselleck”, Redescriptions. Yearbook of Political Thought, Conceptual History and Feminist Theory 16 (1/2013), pp. 215-221.

Palti, Elías José, “Reinhart Koselleck: His Concept of the Concept and Neo-Kantianism”, Contributions to the History of Concepts, 6 (2/2011), pp. 1-20.

Palti, Elías José, An Archaeology of the Political: Regimes of Power from the Seventeenth Century to the Present, New York, Columbia University Press, 2017.

Pankakoski, Timo. "Conflict, Context, Concreteness: Koselleck and Schmitt on Concepts”, Political Theory, 38 (6/2010), pp. 749-779.

Richter, Melvin, "Reconstructing the History of Political Languages: Pocock, Skinner, and the Geschichtliche Grundbegriffe”, History and Theory, 29 (1/1990), pp 38-70.

Sigwart, Hans Jörg, The Wandering Thought of Hannah Arendt, London, Palgrave Macmillan, 2016.

Steinmetz, Willibald, "Some Thoughts on a History of Twentieth-Century German Basic Concepts”, Contributions to the History of Concepts, 7 (1/2012), pp. 78-100.

Steinmetz, Willibald, M. Freeden, and J. Fernández-Sebastián (eds.), Conceptual History in the European Space, New York and Oxford, Berghahn Books, 2017.

Vollrath, Ernst, "Hannah Arendt and the Method of Political Thinking”, Social Research (Summer 1977), pp. 160-182. 